\title{
The beneficial effects of metformin on cancer prevention and therapy: a comprehensive review of recent advances
}

This article was published in the following Dove Press journal: Cancer Management and Research

\author{
Pouya Saraei ${ }^{1}$ \\ Ilia Asadi \\ Muhammad Azam Kakar ${ }^{2}$ \\ Nasroallah Moradi-Kor ${ }^{1,3}$ \\ 'Student Research Committee, Semnan \\ University of Medical Sciences, Semnan, \\ Iran; ${ }^{2}$ Director Planning and \\ Development, L\&DD Department, \\ Quetta, Balochistan, Pakistan; ${ }^{3}$ Research \\ Center of Physiology, Semnan University \\ of Medical Sciences, Semnan, Iran
}

\section{Video abstract}

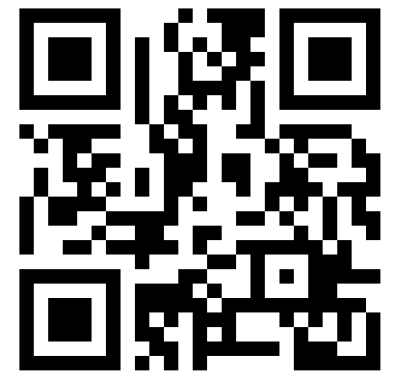

Point your SmartPhone at the code above. If you have a $Q R$ code reader the video abstract will appear. Or use: https://youtu.be/bfluNylzzZA
Correspondence: Nasroallah Moradi-kor Research Centre of Physiology, Semnan University of Medical Sciences, Damghan Road, PO Box 35195-163, Semnan, Iran Tel +982333654207

Email moradikor@semums.ac.ir

\begin{abstract}
Metformin is a widely used drug in today's prescriptions by physicians due to its specific effects in treating and curing type II diabetes. Diabetes is a common disease that may occur throughout human life, and can increase the likelihood of the occurrence of various types of cancer, such as colon, rectum, pancreas and liver cancers, compared to non-diabetic patients. Metformin inhibits mTOR activity by activating ATM (ataxia telangiectasia mutated) and LKB1 (liver kinase B1) and then adenosine monophosphate-activated kinase(AMPK), and thus prevents protein synthesis and cell growth. Metformin can activate p53 by activatingAMPK and thereby ultimately stop the cell cycle. Given the potential of metformin in the treatment of cancer, it can be used in radiotherapy, chemotherapy and to improve the response to treatment inandrogen derivatives (ADT), and also, according to available evidence, metformin can also be used to prevent various types of cancers. Generally, metformin can: 1) reduce the incidence of cancers, 2) reduce the mortality from cancers, 3 ) increase the response to treatment in cancer cells when using radiotherapy and chemotherapy, 4) optimize tumor movement and reduce the malignancy, 5) reduce the likelihood of relapse, and 6) reduce the damaging effects of ADT. Therefore, this drug can be used as a complementary therapeutic agent for cancer treatment and prevention. In this review, we have summarized the data from various experimental and clinical studies and highlight the possible potential effects of metformin on cancer therapeutic responses.
\end{abstract}

Keywords: metformin, AMPK pathway, mTOR pathway, LKB1, radiation, prevention and treatment of cancer

\section{Introduction}

Cancer is a disease in which cell proliferation becomes abnormal and uncontrollable, and it can also involve adjacent tissues in the body. More than 200 different types of cancer are already diagnosed, each of which occur in a specific manner; however, what all of them share is the fact that they all are triggered in the same way: a change in the natural internal structure of a cell. Common features among different types of this disease are: 1) excessive growth signals; 2) failure to respond to anti-growth signals; 3 ) non-scheduled cell death; 4) limitless proliferation potential; 5) angiogenesis; and 6) tissue invasion and metastasis, such that cancer cells can spread via the bloodstream or lymph to other parts of the body. ${ }^{1,2}$ Cancer is the second leading cause of death in the world, according to the WHO; in 2015, 8.8 million people died from it. It is estimated that approximately one out of six people die from cancer around the world; this includes deaths from various types of cancer, such as liver (788,000 deaths), colon (774,000 deaths), stomach (754,000 deaths) and breast (571,000 deaths) cancers. There 
are specific treatments for each type of cancer; however, the main methods used in cancer treatment include surgery, radiotherapy, chemotherapy, hormone therapy (eg, androgen derivatives; ADT) and gene therapy. Diabetes is a common disease that may occur throughout human life, and can be a factor in the occurrence of various types of cancer; also, diabetics are more likely to develop a variety of cancers, such as colon, rectum, pancreas and liver cancers, compared to non-diabetic patients. ${ }^{3}$ Incidence of various cancers is higher among patients with T2DM due to insulin resistance, and mitogenic effects caused by hyperglycemia. ${ }^{3}$ Diabetic mellitus is an ancient disease that was discussed at least 3,600 years ago for the first time in Ebers Papyrus (ancient Egypt). ${ }^{4}$ It was described and categorized as type 1 and 2 by Sushruta and Charaka from about 500 to $600 \mathrm{BC}$ in India. ${ }^{4}$ The discovery and study of diabetes began with the work of Thomas Willis (1675); he was the first to use the term "mellitus", which meant "honey-sweet" due to the specific odor of the urine of diabetic patients. $5^{5,6}$ Metformin was first introduced for therapeutic purposes in 1922 by the Dublin chemists Emile Werner and James Bell. ${ }^{7}$ They found that this compound reduces the amount of glucose in rabbits; however, unlike other similar compounds, it does not affect blood pressure and heart rate. ${ }^{8}$ Metformin is a biguanide and is extracted from the herb Galega officinalis (French lilac, also known as goat's rue or Italian fitch); and it used to treat patients with type II diabetes. ${ }^{9-15}$ Biguanides, including metformin, phenformin, and buformin, were initially used for therapeutic applications for short periods of time; however, since phenformin and buformin cause the production of poison and lactic acid, they are not used anymore. ${ }^{16,17}$ Therefore, today, metformin (N-N-dimethybiguanide hydrochloride, Figure 1) is a commonly used drug due to its known anti-diabetic properties. ${ }^{16,17,18}$

Metformin is a very widely used drug in today's societies due to its specific effects in treating type II diabetes. Metformin decreases fasting and post-fasting glucose, the surrogate marker of glycemic control HbAlc (1-1.5\%) and insulin resistance. ${ }^{19}$ Metformin reduces glycogenesis through adenosine monophosphate-activated kinase (AMPK) signaling, and thus increases glucose uptake in

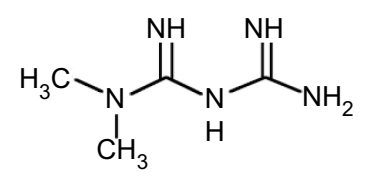

Figure I Molecular structure of metformin. muscle cells in diabetic patients, which leads to a decrease in glucose and insulin levels. ${ }^{19-25}$ It has been shown that this drug can also be used in patients with T1DM, gestational diabetes and pre-diabetes. Based on several clinical trials on animal models in different atmospheres, metformin has shown beneficial therapeutic effects on metabolic syndrome, NAFLD (non-alcoholic fatty liver disease) and hyperlipidemia. ${ }^{26-34}$ The unique features of metformin that distinguish it from other anti-diabetic drugs are that it is cheap and harmless, and has minimal side effects; also, there is evidence of increased survival among patients taking this medication. ${ }^{10,22}$ Another advantage of metformin is that it can be used along with other anti-diabetic drugswith problems. ${ }^{9}$ One of the current therapeutic applications of metformin is in the treatment of polycystic ovarian syndrome (PCOS). ${ }^{10,20,35}$

The hypothesis that biguanides can be used to treat cancer was raised by the introduction and use of phenformin; however, because of the limitations of phenformin (toxicity), metformin is currently the ideal candidate for cancer treatment trials. ${ }^{20}$ Based on recent analyses and studies, metformin reduces the proliferation of cancer cells and the possibility of malignancies in different types of cancer, including gastric carcinoma, pancreatic cancer, uterine cancer, medullary thyroid cancer $^{18}$ and a number of other cancers, such as prostate, colon, pancreas, and breast, as presented in this review. It has also been shown that the use of metformin alone or along with radiotherapy reduced tumor growth in different cancers, such as ovarian, melanoma, prostate, and breast cancer, in a variety of animal models. ${ }^{18,19}$ Generally, metformin inhibits mTOR activity by activating ATM(ataxia telangiectasia mutated), LKB1 (liver kinase B1), and then AMPK; and thereby, it prevents protein synthesis and cell growth.

In this review, we attempt to describe the various explanations for metformin and its therapeutic effects in the following sections: biology of metformin, molecular mechanism of metformin in cancer cells, metformin and clinical studies, metformin and cancer, clinical trials of metformin in cancer treatment, metformin and radiotherapy, conclusion, and future vision. We also discuss metformin and its effects on treatment and prevention of various cancers in diabetic and non-diabetic patients, so that we can observe progress in cancer prevention and treatment. The goal of this review is to update the research field on the multiple roles of metformin in cancer prevention and treatment. In this review, we have searched Web 
of Science and PubMed databases and finally used a total of 98 published articles to summarize the recent advances in cancer treatment and prevention with metformin. All abbreviations used in this review are shown in Table 3.

\section{Biology of metformin}

According to the literature, the anti-carcinoma effects of metformin are often results of the following mechanisms: 1) activating LKB1 and AMPK and inhibiting mTOR activity; 2) inhibiting protein synthesis; 3) stopping the cell cycle; 4) triggering apoptosis and autophagy by p53 and p21; 5) decreasing blood insulin levels; 6) inhibiting the unfolded protein response (UPR); 7) activating the immune system; 8) destructing cancer stem cells; 9) preventing angiogenesis; and 10) reducing hyperlipidemia.

Metformin inhibits mTOR (the mammalian target of rapamycin) activity by activating AMPK and LKB1, resulting in protein synthesis and cell growth. ${ }^{15,22,23,24}$ Naturally, in hyperglycemic cells, LKB1 levels are low and glucose production processes increase due to the low sensitivity of insulin receptors. Metformin during the chain processes activates LKB1 and, therefore, AMPK activity, thereby inhibiting mTOR activity. ${ }^{18,20}$ All of these actions will probably reduce protein synthesis and angiogenesis. The result of AMPK activity is disruption in two processes that both play a very important role in cell growth: 1) mTOR; 2) elongation of factor 2. AMPK also inhibits mTOR activity through two methods: 1) phosphorylating co-signaling molecules, 2) activating TSC2 (tuberculous sclerosis complex 2). AMPK inhibits MTOR activity by phosphorylation of TSC2; it also can directly phosphorylate co-signaling molecules, which results in attachment of these molecules to mTOR, and the inhibition of mTOR activity. ${ }^{18,20,36}$ Evidence suggests that the presence of mTOR is required for the activity of a factor called hypoxic inducible factor (HIF-1). HIF-1 is a key regulator of transcription that enables genes and cells to adapt to hypoxia and can cause cancer cell resistance in radiotherapy. Therefore, AMPK can indirectly inhibit HIF-1 activity and the growth of cancer cells in hypoxia. ${ }^{18,20}$

According to Anisimov et al, metformin reduces the risk of cancer. They obtained this result from experiments on breast cancer cells in mice. ${ }^{37}$ One of the reasons for extensive studies on breast cancer cells is the treatment of these cells by metformin, which will be able to prevent the growth of breast cancer cells by AMPK and LKB1 by inhibition of translation in breast cancer cells. Also, metformin has been shown to inhibit mTOR activity by reducing phosphorylation of S6Ks (ribosomal protein S6 kinase). An interesting point regarding metformin is its ability to prevent aromatase, which is involved in estrogen production, which can then prevent the growth and spread of tumors in the breast. For this reason, metformin can be used as a complementary therapeutic method for the treatment of breast cancer. ${ }^{18,20,38,39}$

Metformin may also prevent the encoding of genes that are responsible for the production of ribosomal proteins or proteins involved in the expression of other genes. An interesting point about cancer cells is the expression and enhancement of insulin-like growth factor receptor (IGF-R). IGF is a growth factor similar to insulin, and its activity leads to cell growth. The activity of these receptors or IGF-R in the cell leads to increased glucose uptake and high cell proliferation. Insulin also reduces the IGF-binding proteins (such as IGFBP-I, IGFBP-II, IGFBP-III), and therefore, the level of IGF increases in the blood resulting in cell growth and proliferation. ${ }^{17,20,40}$ Generally, hyperinsulinemia causes a lot of problems including increased levels of IGF, epithelial tissue proliferation and increased variation steroid sexual hormones in the body of patients. Increased levels of IGF in the blood cause other problems, including increased angiogenesis.

Another anti-cancer activity of metformin is the prevention of UPR activity. UPR is a vital activity for the survival of cells. When the cell is in stress conditions (blood glucose reduction) this activity will increase in the cell and resolve its needs. Metformin inhibits UPR activity in stressed conditions, according to studies, and forces cancer cells to undergo apoptosis and ultimately die. ${ }^{41}$ It has also been shown that metformin prevented cell growth in breast carcinoma by decreasing HER2 (erb-B2, epidermal growth factor receptor 2) level. ${ }^{3,16}$ Several studies suggest selective elimination ofcancer stemcells due to the use of metformin. For example, Hirsch et al stated that the use of low doses of metformin eliminates cancer cells selectively. Other researchers have also shown that the use of metformin along with chemotherapy reduces not only the size of the tumor but also the risk of malignity and tumor displacement to other organs in the body. ${ }^{42,43}$

\section{Molecular mechanism of metformin in cancer cells}

Metformin is thought to have an anti-tumor effect by lowering insulin levels and disabling the mammalian target of rapamycin (mTOR) in the cell. Metformin is introduced into the cell via OCT-3 and OCT-1 (organic cation transporter 1,3) and affects complex I of the electron transfer chain (ETC) and the enzyme called mGPD (mitochondrial glycrophosphate 3 dehydrogenase); ${ }^{44-46}$ thereby, it blocks complex I activity, 
reduces oxygen consumption and the production of ATP (adenosine triphosphate), and puts the cell under stress conditions. $^{47-54}$ With inhibition of complex I activity and reduction of ATP, the level of AMP (adenosine monophosphate) will increase within the cell. The increase of the ratio of AMP to ATP, or in other words, increase of the level of AMP in the cell, activates AMPK, which is an energy sensor. ${ }^{48-60}$ Generally, AMPK plays a significant role in regulating the amount of energy in the cell, and its activity in the cell enhances catabolism processes (that increase ATP) and reduces anabolism processes (that reduce ATP). ADP also prevents the dephosphorylation of AMPK. Another effect of AMP increase in the cell is the inhibition of adenylate cyclase activity, through which glucagon effect is neutralized and glycogenosis is reduced. One of the metformin anticancer effects reported in several studies is the activation of ATM and LKB1. ${ }^{18,24,61}$ Both LKB1 and ATM are proteins that play an important role in controlling and regulating the cellular cycle. LKB1 is a tumor suppressor, and its activity results in apoptosis or cellular autophagy and it regulates AMPK activity in the cell. ATM, as well as LKB1, is a tumor suppressor. ATM responds to the metformin introduction into a cell by phosphorylating LKB and thereby activates AMPK. ${ }^{18,24,61}$

Here some vital points need to be stated regarding the insulin mechanism in diabetic patients. In general, when food enters the human body, liver cells increase levels of IGF, IGFreceptor, and insulin-receptor. Next, mTOR is indirectly activated in the chain processes of signal transmitting from IRS (insulin receptor substrate) to PI3K (phosphoinositide 3-kinase) and then Akt (PKB, protein kinase B), and inactivating TSC2. ${ }^{62}$ TSC2 is a tumor suppressor, and activated mTOR inhibits its activity. With the activation of mTOR in the cell, cell growth, and proliferation increase. There is evidence of an anticancer effect of metformin through the inhibition of mTOR activity. ${ }^{17}$ Many studies indicate an increased risk of cancers as a result of increased mTOR activity. On the one hand, some studies have shown that metformin lowers the level of insulin and mTOR activity. ${ }^{18,20,22,23,24}$ Therefore, considering this evidence, metformin may reduce the growth and proliferation of cancer cells; then it can be used for the complementary treatment of cancer. According to in vivo and in vitro results, metformin, by reducing the expression of G1 cyclins, causes a barrier against the activity of the G1 cell cycle and thus halts the cycle of the cell. ${ }^{4,24}$

Generally, metformin has anti-tumor effects through two mechanisms: 1) a direct mechanism (independent of insulin); and 2) an indirect mechanism (insulin-dependent). In the indirect mechanism, metformin activates AMPK, which results in AMPK preventing the transcription of the gene responsible for glycogenesis in liver cells (Figure 2). In this process, glycogenosis decreases and, as a result, glucose uptake in muscle cells increases. Glucose uptake in the muscle cells leads to a decrease in blood glucose levels and subsequently insulin levels. Since high levels of insulin in the blood, due to the high number of insulin receptors in the cancer cells, have mitogenic effects and can cause tumor growth and proliferation, reducing insulin levels in the blood reduces the likelihood of malignity and prevents cancer cell proliferation. ${ }^{20-24}$ It should also be noted that patients with type II diabetes, due to the low sensitivity of their cells to insulin (insulin resistance) compared to other patients, are more at risk for various types of cancers due to mitogenic effects of insulin that cause excessive cell growth. For example, several studies have shown metformin use to lower insulin levels in the blood for the treatment of breast cancer in women. ${ }^{10,20}$ Studies have also shown that there is an increased risk of various cancers, including colon, breast, pancreas and uterus cancers in diabetic and obese patients. $^{20}$ The direct effect of metformin (independent of insulin) is related to the activation of AMPK and the inhibition of mTOR activity. ${ }^{63-66}$ The activation of AMPK during the above-mentioned process results in activation of TSC2, and thus mTOR activity reduction. Preventing mTOR activity reduces the levels of 4E-BPs (4E-binding proteins) and S6Ks (ribosomal protein S6 kinase) factors and decreases protein synthesis and proliferation. Thus, the metformin affects AMPK and mTOR and inhibits cancer cell growth and proliferation. ${ }^{4,10,21}$ Other studies have also shown that activation of AMPK can reduce fatty acid synthase (FAS). ${ }^{10,24}$ On the other hand, AMPK can activate ACC (acetyl coenzyme A carboxylase) and thus can increase the level of ATP in the cell. ${ }^{10,23}$ ACC is responsible for the cellular metabolism regulation by reducing anabolism processes and increasing catabolism processes. ${ }^{23}$

\section{Clinical studies of metformin on cancer therapy}

One of the advantages of metformin, which demonstrates its high potential for increasing the therapeutic response in cancer cells observed in several animal models, is the prevention of the proliferation and growth of tumors. For example, there is evidence for metformin preventing the growth of cancer cells in lung, prostate, colon, and genograph. ${ }^{67-70}$ Since 2005, metformin has been reported to reduce the risk of cancer by up to $23 \%$ worldwide. For 

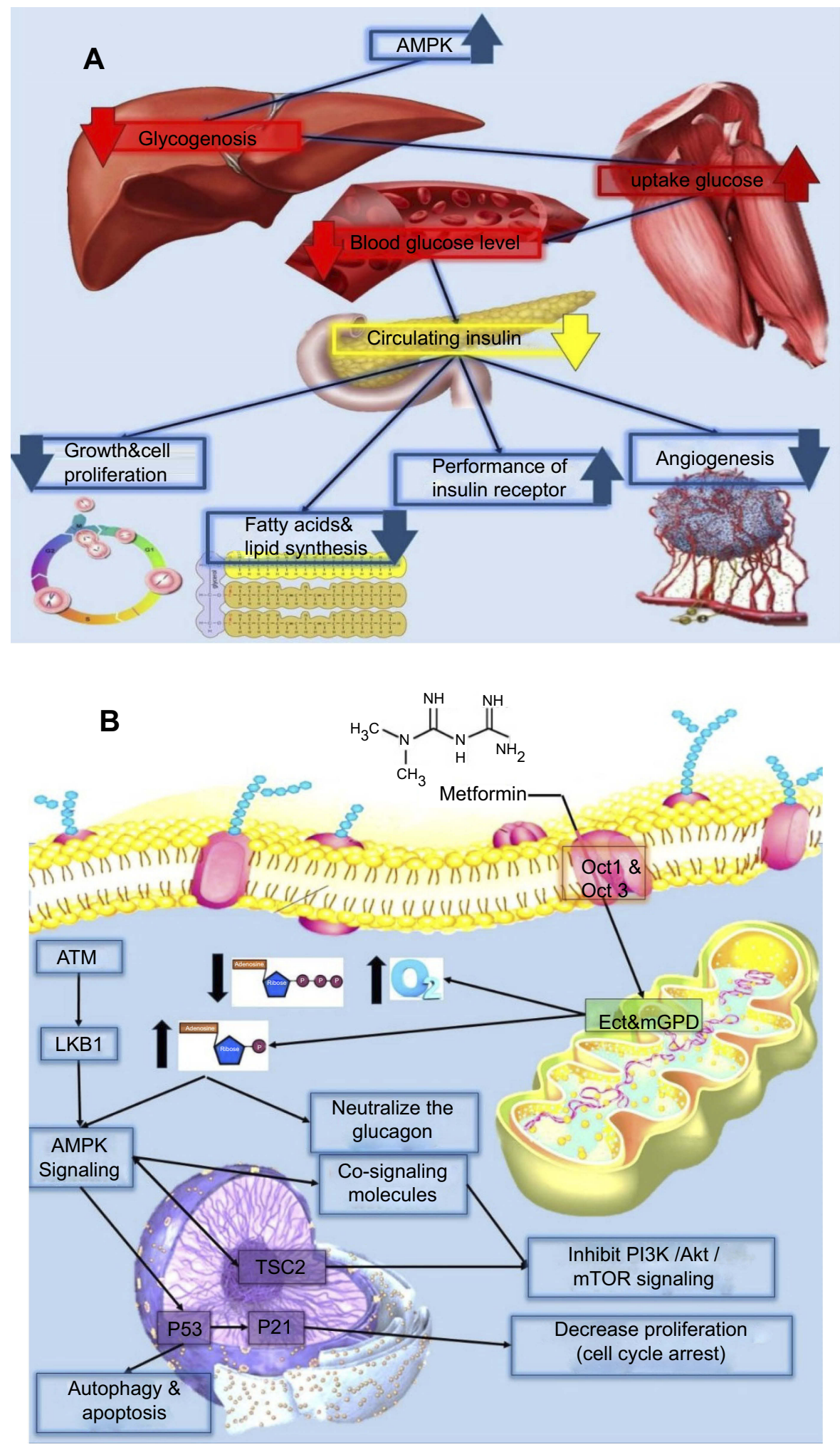

Figure 2 Overview of the indirect (A) and direct (B) molecular mechanism of metformin.

example, the results of the Taiwan National Health Insurance Data Survey, which included a community of 12,005 patients taking metformin from 2000 to 2007 and a population of 4,597 patients taking other oral medications, indicated that using metformin reduces the chance of any type of cancers up to $88 \% .{ }^{9,71}$ According to the results 
of Decensi et al (2010), the likelihood of developing cancer in type II diabetic patients using metformin is $30 \%$ lower than that of patients taking other drugs. ${ }^{18,72}$ Therefore, taking into account the above-mentioned results, it can be concluded that the mortality due to cancer among patients taking metformin will be less. Moreover, the results of the ZODIAC trial showed a lower incidence of death among metformin-taking patients. ${ }^{20,73}$ One of the largest studies on the probability of cancer incidence examined 60,000 patients and showed that patients who use insulin or other similar drugs are more likely to have solid cancers in the future, compared to metformin users. $^{20,74}$ In a similar study, Bowker et al examined three groups of T2DM patients who used sulfonylurea, insulin, and metformin and reported that mortality risk was higher in the first two groups of patients compared to metformin-taking patients. In their study, the incidence of death per 1,000 patients taking sulfonylurea, metformin, and insulin, who were under observation for one year, was 4.9, 3.5 and 8.8, respectively. ${ }^{20}$ According to Soranna et al patients using sulfonylurea were more prone to different types of cancers than those who used metformin to control their diabetes. ${ }^{75}$ Noto et al studied risk ratio (RR) of 21,195 diabetic patients and reported a lower risk of developing cancers and deaths due to cancers among diabetic patients who used metformin to control their diabetes. ${ }^{76}$

A recent study conducted by Libby et al on 8,000 T2DM patients suggested a lower incidence of cancer for those who use metformin $(7.3 \%)$ than those who do not use metformin. ${ }^{10}$ According to the results of Higurashi et al the use of metformin (in low doses) in one year reduced the likelihood of occurrence of metachronous colorectal adenomas (MCA) and polyps in patients who had polypectomy. ${ }^{77}$ Some other studies have also shown that metformin can inhibit the proliferation of cancer cells of breast, uterus, ovary, colon, and prostate. For example, Joshua et al, examining the prostatectomy samples of non-diabetic patients who used metformin for a short time (41 days) before surgery, found that $\mathrm{Ki67}$ (a marker for cell proliferation) in these cells decreased by $30 \%$ per person. ${ }^{78}$ According to studies conducted on non-diabetic women with earlystage breast cancer, the use of metformin in this group reduced the amount of insulin by $22 \%$. Furthermore, according to a study by Campagnoli et al on women with breast cancer, the use of metformin reduced the level of testosterone and insulin and its destructive effects, such as insulin resistance. ${ }^{79}$
Moreover, another study conducted by Monami et al, following up 195 patients over a period of 9.6 years, stated that exposure to metformin for more than 36 months was associated with a significant reduction in the risk of cancer. ${ }^{80}$ Results of the data analysis from a study by Home et al revealed no difference in cancer incidence between patients treated with metformin and patients treated with rosiglitazone, without refuting the possibility of a difference compared with sulfonylureas. ${ }^{81} \mathrm{~A}$ recent larger study by Baur et al revealed that included more than 7,000 patients found a higher prevalence of malignancies (66/1,308 patients) in subjects with type 2 diabetes mellitus compared to nondiabetic subjects (185/6,211 patients) before and after adjustment for several confounding factors. ${ }^{82}$ Also, Li D et al examined whether metformin use is associated with better outcomes after chemotherapy in various types of cancer, and found that diabetic patients who had taken metformin had a significantly lower risk of pancreatic cancer compared with those who had not taken metformin. ${ }^{83}$ Berstein et al analyzed the receptor status of breast carcinomas in 90 post-menopausal women affected with diabetes mellitus type 2 who had been cured, for not less than one year prior to surgery, with different modes of antidiabetic therapy, including a dietary treatment only, sulfonylurea preparations, insulin therapy, and metformin as a monotherapy or in combination with sulfonylurea derivatives. The outcomes for this study recommended that metformin is a better treatment model in women, compared with sulfonylurea or insulin. ${ }^{84}$ Other researchers also examine the effects of metformin in patients with prostate cancer (diabetic or non-diabetic). For example, Rieken et al reported betterrecurrence-free survival(RFS) in 6,863 patients treated with radical prostatectomy. ${ }^{85}$ Also according to the results of Spratt et al using metformin may improve patients' PSA, RFS, OS, and reduce the development chance of prostate cancer. ${ }^{86}$ Finally, based on the study by Margel et al, using metformin decreases both the likelihood of relapse and mortality in patients with prostate cancer. ${ }^{87}$ Other clinical studies are summarized and shown in Table 1.

\section{Metformin in cancer prevention and therapy}

There are a number of published studies and observations that indicate a reduction in the risk of cancer and its mortality among diabetic patients that use metformin in doses of 1,500-2,250 mg per day. ${ }^{88-91}$ Evans et al 
Table I A summary of clinical studies of metformin effects on cancers

\begin{tabular}{|c|c|c|c|c|c|}
\hline Study & $\begin{array}{l}\text { Number of } \\
\text { Patients }\end{array}$ & Year & Intervention & Outcome & $\begin{array}{l}\text { Cancer } \\
\text { Type }\end{array}$ \\
\hline $\begin{array}{l}\text { Taiwan National } \\
\text { Health Insurance } \\
\text { Data Survey Lee } \\
\text { MS et al }\end{array}$ & $\begin{array}{l}\text { - Total: } 12,005 \\
\text { - Patients using met- } \\
\text { formin: } 4,597\end{array}$ & 2011 & $\begin{array}{l}\text { Drug: metformin } \\
\text { (orally) }\end{array}$ & $\begin{array}{l}\text { Metformin reduces the chance of cancers up } \\
\text { to } 88 \%\end{array}$ & Various \\
\hline Decensi et $\mathrm{al}^{72}$ & $\begin{array}{l}\text { Total: } 4,042 \text { cancer } \\
\text { events and } 529 \text { cancer } \\
\text { deaths }\end{array}$ & 2010 & $\begin{array}{l}\text { Drug: metformin } \\
\text { (orally) }\end{array}$ & $\begin{array}{l}\text { Likelihood of developing cancers in patients } \\
\text { using metformin is } 30 \% \text { lower than that of } \\
\text { patients taking other drugs }\end{array}$ & Various \\
\hline Bowker et al ${ }^{90}$ & 1,000 & 2006 & $\begin{array}{l}\text { Drug: metformin, sulfo- } \\
\text { nylurea and insulin }\end{array}$ & $\begin{array}{l}\text { Incidence of death of medications users: } 3.5 \text {, } \\
4.9 \text { and } 8.8 \text { respectively }\end{array}$ & Various \\
\hline Landman et $\mathrm{al}^{73}$ & 1,353 & 2010 & Drug: metformin & $\begin{array}{l}\text { Mortality was lower in patients taking } \\
\text { metformin }\end{array}$ & Various \\
\hline Currie et $\mathrm{al}^{74}$ & 60,000 & 2009 & $\begin{array}{l}\text { Drug: metformin, sulfo- } \\
\text { nylurea and insulin }\end{array}$ & $\begin{array}{l}\text { Patients who use insulin or other similar drugs } \\
\text { compared to metformin users are more likely } \\
\text { to have solid cancers in future }\end{array}$ & $\begin{array}{l}\text { Colon, } \\
\text { pancreas, } \\
\text { breast and } \\
\text { prostate }\end{array}$ \\
\hline Soranna et $\mathrm{al}^{75}$ & Not provided & 2012 & $\begin{array}{l}\text { Drug: metformin and } \\
\text { sulfonylurea }\end{array}$ & $\begin{array}{l}\text { Metformin, but not sulfonylurea, appears to } \\
\text { reduce subsequent cancer risk }\end{array}$ & Various \\
\hline Noto et $\mathrm{al}^{76}$ & $\begin{array}{l}\text { Patients using met- } \\
\text { formin: } 21,195 \\
\text { - Cases of death from } \\
\text { cancer in these } \\
\text { patients: } 991\end{array}$ & 2012 & Drug: metformin & $\begin{array}{l}\text { The use of metformin in diabetic patients was } \\
\text { associated with significantly lower risks of } \\
\text { cancer mortality and incidence }\end{array}$ & Various \\
\hline Libby et al ${ }^{88}$ & 8,000 & 2009 & Drug: metformin & $\begin{array}{l}\text { Cancer was diagnosed in } 7.3 \% \text { of metformin } \\
\text { users compared with } 11.6 \% \text { of non-users }\end{array}$ & Various \\
\hline Higurashi et $\mathrm{al}^{77}$ & 498 & 2016 & Drug: metformin & $\begin{array}{l}\text { Low-dose metformin reduced the prevalence } \\
\text { and number of metachronous adenomas or } \\
\text { polyps after polypectomy and metformin has } \\
\text { a potential role in the chemoprevention of } \\
\text { colorectal cancer }\end{array}$ & $\begin{array}{l}\text { Colorectal } \\
\text { adenoma } \\
\text { or polyps }\end{array}$ \\
\hline Joshua et $\mathrm{al}^{78}$ & 24 & 2014 & Drug: metformin & $\begin{array}{l}\text { Neoadjuvant metformin is well tolerated prior } \\
\text { to radical prostatectomy and data to date } \\
\text { indicate promising effects on metabolic and } \\
\text { tissue proliferation and signalling parameters }\end{array}$ & $\begin{array}{l}\text { Prostate } \\
\text { cancer }\end{array}$ \\
\hline Campagnoli et $\mathrm{al}^{79}$ & 125 & 2012 & Drug: metformin & $\begin{array}{l}\text { Using of metformin reduced the level of tes- } \\
\text { tosterone and insulin and its destructive } \\
\text { effects, such as insulin resistance }\end{array}$ & $\begin{array}{l}\text { Breast } \\
\text { cancer }\end{array}$ \\
\hline Evans et $\mathrm{al}^{92}$ & Not provided & 2005 & Drug: metformin & Using metformin decreased cancer incidence & Various \\
\hline Monami et $\mathrm{al}^{80}$ & 195 & 2009 & $\begin{array}{l}\text { Drug: metformin and } \\
\text { sulfonylurea }\end{array}$ & $\begin{array}{l}\text { Exposure to metformin for more than } 36 \\
\text { months was associated with a significant } \\
\text { reduction in the risk of cancer }\end{array}$ & Various \\
\hline Home et $\mathrm{al}^{81}$ & 105 & 2010 & $\begin{array}{l}\text { Drug: metformin, rosigli- } \\
\text { tazone and glibenclamide }\end{array}$ & $\begin{array}{l}\text { No difference in cancer incidence between } \\
\text { patients treated with metformin and patients } \\
\text { treated with rosiglitazone }\end{array}$ & Various \\
\hline
\end{tabular}


Table I (Continued).

\begin{tabular}{|c|c|c|c|c|c|}
\hline Study & $\begin{array}{l}\text { Number of } \\
\text { Patients }\end{array}$ & Year & Intervention & Outcome & $\begin{array}{l}\text { Cancer } \\
\text { Type }\end{array}$ \\
\hline $\begin{array}{l}\text { Baur et } \mathrm{al}^{82} \\
\text { Li D et } \mathrm{al}^{82}\end{array}$ & $\begin{array}{l}7,000 \\
973\end{array}$ & 2010 & $\begin{array}{l}\text { Drug: metformin and } \\
\text { insulin } \\
\text { Drug: insulin, insulin } \\
\text { secretagogues, metfor- } \\
\text { min, and other antidia- } \\
\text { betic medications }\end{array}$ & $\begin{array}{l}\text { Patients on metformin had a lower prevalence } \\
\text { of malignancies, comparable with that among } \\
\text { nondiabetic patients } \\
\text { Metformin use was associated with reduced } \\
\text { risk, and insulin or insulin secretagogue use } \\
\text { was associated with increased risk of pan- } \\
\text { creatic cancer in diabetic patients. }\end{array}$ & $\begin{array}{l}\text { Various } \\
\text { Pancreatic } \\
\text { cancer }\end{array}$ \\
\hline Berstein et $\mathrm{al}^{84}$ & 90 & 2010 & $\begin{array}{l}\text { Drug: metformin, sulfo- } \\
\text { nylurea and insulin }\end{array}$ & $\begin{array}{l}\text { Better treatment in women who were treated } \\
\text { with metformin compare with sulfonylurea or } \\
\text { insulin }\end{array}$ & $\begin{array}{l}\text { Breast } \\
\text { cance }\end{array}$ \\
\hline Rieken et $\mathrm{al}^{85}$ & $\begin{array}{l}\text { Total: } 6,863 \\
\text { Patients with T2DM } \\
\text { on metformin: } 287 \\
\text { - Patients with T2DM } \\
\text { on other antidia- } \\
\text { betic medications: } \\
377\end{array}$ & 2014 & Drug: metformin & $\begin{array}{l}\text { Better RFS in patients treated with radical } \\
\text { prostatectomy for prostate cancer }\end{array}$ & $\begin{array}{l}\text { Prostate } \\
\text { cancer }\end{array}$ \\
\hline Spratt et $\mathrm{al}^{86}$ & $\begin{array}{l}\text { - Total: } 2901 \text { patients } \\
\text { - } 157 \text { on metformin } \\
\text { - } 162 \text { diabetic non- } \\
\text { metformin } \\
\text { - } 2,582 \text { nondiabetic }\end{array}$ & 2013 & Drug: metformin & $\begin{array}{l}\text { Using metformin may improve patients' PSA, } \\
\text { RFS, OS, and reduce the development chance } \\
\text { of prostate cancer }\end{array}$ & $\begin{array}{l}\text { Prostate } \\
\text { cancer }\end{array}$ \\
\hline Margel et $\mathrm{al}^{87}$ & 3,837 & 2013 & Drug: metformin & $\begin{array}{l}\text { Using metformin decreases both likelihood of } \\
\text { relapse and mortality }\end{array}$ & $\begin{array}{l}\text { Prostate } \\
\text { cancer }\end{array}$ \\
\hline
\end{tabular}

explained that the likelihood of incidence of cancer in patients who use metformin is less than those who do not use this drug. ${ }^{92}$ In addition, a study on 2,529 women with breast cancer suggested an increase in pCR (pathologic complete response) among diabetic patients using metformin compared to diabetic and non-diabetic patients not using metformin. ${ }^{16}$ Recent studies also show that even using low doses of metformin reduces the risk of rectal cancer, as metformin inhibits the growth of cancer cells and reduces their proliferation. For example, according to some evidence, metformin has been shown to inhibit the proliferation of breast, prostate, colon, uterine, ovarian, and glioma cancer cells. ${ }^{37,42}$ Metformin anti-proliferative effects on cancer cells are associated with AMPK activation, inactivation of the mTOR mechanism, reduction of EFGR (epidermal growth factor receptor) and MAPK (mitogen-activated protein kinase), reduction in the expression and activity of cyclins and expression of p27 gene. Since mTOR function in cells is the growth and synthesis of proteins and production of fat, therefore, metformin inhibits the growth and proliferation of cells by inhibiting mTOR activity. ${ }^{36,61,65}$ The use of metformin improves the RFS $(n=623)$ and OS $(n=1,936)$ and cancerspecific survival (CSS) $(n=533)$ indicators in patients with colorectal cancer. ${ }^{93}$ Also, Langley et al, one of the great oncologists in the UK, regarding the effectivity of metformin in the treatment of cancer, stated that patients taking metformin had a better recurrence-free overall (RFO) and CSS than those who did not use metformin. ${ }^{22}$ There is also evidence of a reduction in the proliferation of cancer cells in colon cancer. For example, according to Hosono et al, low doses of metformin $(250 \mathrm{mg} /$ day $)$ were associated with the destruction of aberrant crypt foci (ACE) which is a marker related to the presence of colon cancer. ${ }^{94}$

According to different published studies, the use of metformin (high doses) reduces the likelihood of death in patients with colorectal cancer. This study was carried out in 2001-2006 on diabetics who used metformin 
prior to the diagnosis of cancer $(\mathrm{n}=207)$, and diabetic $(n=108)$ and non-diabetic patients $(n=3,501)$ who did not use metformin. ${ }^{21}$ Also, according to Garrett's results, the use of metformin reduced the likelihood of mortality in patients with colorectal cancer grade one to four by $40 \% .{ }^{95}$ Metformin also improves RFS, OS, and CSS indicators in patients with prostate cancer. ${ }^{93}$ Prostate cancer is one of the common diseases in societies and the second leading cause of death among men. ${ }^{10}$ According to some evidence, metformin can be used to treat cancers such as prostate cancer. For example, several studies have reported an increase in OS index and a reduction in prostate cancer risk due to metformin use. ${ }^{10}$ Moreover, according to a study on patients with prostate cancer (early stage), metformin users had a better OS, CSS, and RFO. According to an analysis of patients with prostate cancer, metformin reduced the likelihood of recurrence of disease by $18 \% .^{11}$ Oliveria et al also showed that the use of metformin in diabetic patients reduces the risk of pancreatic cancer. ${ }^{96}$ Ruiter et al investigated the risk of pancreatic cancer in patients taking metformin and sulfonylurea and indicated that using metformin reduces the risk of pancreatic cancer. ${ }^{97}$

Metformin also improves RFS ( $\mathrm{n}=271$ ) in patients with breast cancer; no change in the OS index $(n=2,045)$ have been reported in this study population. ${ }^{93}$ According to the results of Bodmer et al the risk of breast cancer in people taking metformin for more than 5 years was decreased. ${ }^{98}$ Furthermore, according to the results of research by Jiralespnog et al on diabetic $(\mathrm{n}=155)$ and non-diabetic $(n=2,374)$ patients with breast cancer, pathologic complete remission $(\mathrm{pCR})$ of patients taking metformin along with chemotherapy was higher compared to patients who did not receive metformin. ${ }^{99}$ Other related studies have also shown that metformin has reduced the likelihood of developing liver cancer by $62 \%$ in T2DM patients. ${ }^{17}$ There are studies regarding head and neck cancer that show an increase in RFS and CSS as a result of metformin use (there is no change in the OS). ${ }^{93}$ This study also indicates increased OS in lung cancer or increased RFS and OS in cervical cancer or increased OS and CSS in gastric cancer (also called stomach cancer). ${ }^{93}$ Among the important factors that cause the results of these indexes to be different, one can point out differences in patient characteristics, tumor type, and tumor biology. In general, according to reports, related articles, as well as animal and human models, the risk of cancer is reduced by the use of metformin, especially in diabetic patients. ${ }^{18}$

\section{Clinical trials of metformin in cancer therapy}

Several clinical studies have been conducted to improve the therapeutic response when using metformin. ${ }^{20,93}$ The goal of all these experiments was to investigate the ability of metformin to treat cancer. One of the greatest clinical trials conducted to date is called NCT01101438. NCT01101438 is a 3-phase experiment that examines the efficacy of metformin in the treatment of cancers such as breast cancer, nonmetastatic cancers, and cancers with a low degree of malignity. According to the results of the study, metformin improved patients' progression-free survival (PFS). ${ }^{93}$ This trial was with 3,582 people and examined whether metformin in patients with a primary stage, non-metastatic breast cancer is superior to placebo. Patients received metformin twice a day for 5 years after diagnosis. Patients with prior use of metformin, insulin or other oral hypoglycemia were excluded. The results of the study showed that metformin improved patients' PFS. ${ }^{20,93}$ Also two phase II tests including pancreatic cancer were carried out. So far, gemcitabine combined with other agents has shown a modest, but statistically significant, benefit in OS in patients with advanced disease. ${ }^{20}$ The NCT01167738 trial registered 82 patients and examined a 6-month metformin daily dose without progression (PFS), in addition to the combination of chemotherapy (cisplatinum, epirubicin, capecitabine, and gemcitabine) compared to combined chemotherapy alone in patients with pancreatic cancer metastasis. Patients were excluded from the study if they had previously used metformin. NCT01210911 also registered 120 patients who were examined whether a dose of $1,000 \mathrm{mg}$ twice daily in the 6-month period of metformin in combination with erlotinib and gemcitabine is more effective than the combination of these two agents in prolonging PFS. Consumers before metformin and patients with uncontrolled diabetes were also excluded from the study. ${ }^{20}$ A phase II trial employed 106 patients to study castration-resistant prostate cancers (NCT01215032) and tested whether metformin improves prostate-specific antigen (PSA) response $(50 \%$ or more) in addition to androgen derivatives (ADT). Metformin was given twice a day for 12 months. In this study, diabetic patients or former metformin users were excluded from the study and glycemic control was a secondary outcome. ${ }^{20}$ One of the clinical trials that studies how well metformin works compared to placebo in treating patients with prostate cancer undergoing surgery is NCT01433913. This randomized phase II trial study reported that metformin may make some enzymes active. These enzymes may block other enzymes 
needed for cell growth and stop the growth of tumor cells. NCT01433913 studied varietal effects of metformin in a different condition, such as adenocarcinomas of the prostate and stage I, IIA and IIB prostate cancer. Also, NCT00659568 (a phase I trial) studied the side effects and best dose of metformin when given together with temsirolimus in treating patients with metastatic or unresectable solid tumor or lymphoma. One of the ongoing clinical trials is NCT01666730 (phase II trial) that studies the effects of metformin and some drugs in chemotherapy such as leucovorin calcium, fluorouracil, and oxaliplatin. According to this trial, drugs used in chemotherapy work in different ways to stop the growth of tumor cells, either by killing the cells or by stopping them from dividing. Giving metformin together with combination chemotherapy may kill more tumor cells. Other clinical trials are summarized and shown in Table 2.

\section{Metformin and radiation therapy}

Several studies have shown increased intrinsic sensitivity of cells due to the use of metformin (in combination with radiotherapy), measured by markers such as phosphorylation of histone $\mathrm{H} 2 \mathrm{AX}$ protein or olive tail moment. ${ }^{11}$ As mentioned before, metformin affects complex I of the electron transfer chain and thereby reduces oxygen consumption and increases ROS (reactive oxygen species) in the cell. As a result of increased ROS in the cell, damage to the DNA increases and the production of protein and fat decreases. There is also evidence of a metformin-induced reduction in glutathione in the cell. ${ }^{15,19}$ Glutathione, a (three amino acids) polypeptide, is in the antioxidant category and can prevent DNA damage. Therefore, metformin can increase the likelihood of damage to DNA. Hence, in general, metformin when used in combination with radiotherapy can cause damage to the DNA and the death of cancer cells by increasing the level of ROS. ${ }^{100-103}$ A review of several articles and experiments suggests that the response to radiation therapy in cancer cells increases with metformin use. For example, in a study on a population of 504 patients with prostate cancer, the likelihood of recurrence of disease or malignity of the cancer was reduced in patients who used metformin $(n=114)$. Several cases have been reported that patients with head and neck squamous cell carcinoma (HNSCC) who underwent radiotherapy (after surgery) showed no sign of illness recurrence. ${ }^{19,104}$

According to a study conducted on two different statistical populations, patients with esophagus cancer $(n=285)$ and patients with rectal cancer $(n=472)$, using metformin with radiotherapy or chemotherapy increased the response of cancer cells to the treatment. ${ }^{11}$ So when metformin is used with chemotherapy, tumor volume and weight, as well as the growth of the cancer stem cells, decrease. ${ }^{11}$ In another group of patients with esophagus cancer, the response to radiation therapy was higher for those who received metformin $(n=29)$ compared to non-diabetic $(n=235)$ or diabetic patients who used other anti-diabetic drugs $(n=21) .{ }^{67,104}$ Similar results are available for other patients with rectal cancer. ${ }^{19}$ A study was conducted on patients with rectal cancer who underwent chemoradiotherapy treatment with metformin from 2007 to $201 .^{63}$ The statistical population of this study included three groups, diabetic patients using metformin $(n=42)$, and diabetic $(n=29)$ and non-diabetic patients $(n=472)$ who did not use metformin. The result of the study showed that patients using metformin who were treated with chemoradiotherapy had a better response to treatment than the other two groups. One of the factors affecting the response of patients who did not use metformin is the high levels of insulin and insulin resistance. Several papers suggest that metformin increases cell sensitivity by lowering insulin levels, increasing apoptosis, increasing oxygen in the tumor, and increasing the damage to DNA, thereby causing the death of cancer cells. ${ }^{63}$

Metformin can activate p53 by activating AMPK, thereby stopping the cell cycle. The expression of the p53 gene is regulated by AMPK, and the presence of AMPK leads to the expression of this gene. P53 gene is a tumor suppressor, and the activity of this gene leads to autophagy and apoptosis. ${ }^{4,15,24}$ Also, according to other related studies, radiotherapy for the treatment of cancer cells triggers a series of chain mechanisms that ultimately lead to a decrease or end of the cell cycle. ${ }^{105}$ This is very similar to the mechanism of metformin in cancer cells; both radiotherapy and metformin activate p53 gene. Metformin, like radiotherapy, activates the p53 gene, resulting in a rapid transcription of the $\mathrm{p} 21$ gene, which itself is a tumor suppressor. The activity of this gene results in the activity of the inhibitors of CDK (cyclindependent kinase), such as CDKN1A, which are barriers of cell division. This gene also forces the cell to apoptosis. Therefore, the $\mathrm{p} 21$ gene can reduce the proliferation of cancer cells and also stop the cellular cycle by regulating and applying therapy-induced cellular senescence (TCS). ${ }^{18,20,23,105}$

In another study on three types of MEF (mouse embryonic fibroblasts), HCT16 (colon carcinoma) and A549 (lung carcinoma) cells, the use of radiotherapy (4 Gy) along with metformin reduced mortality and increased surviving fraction. ${ }^{23}$ Iliopoulos et al stated that breast, prostate, and lung cancer cells showed a greater response when chemotherapy was used 


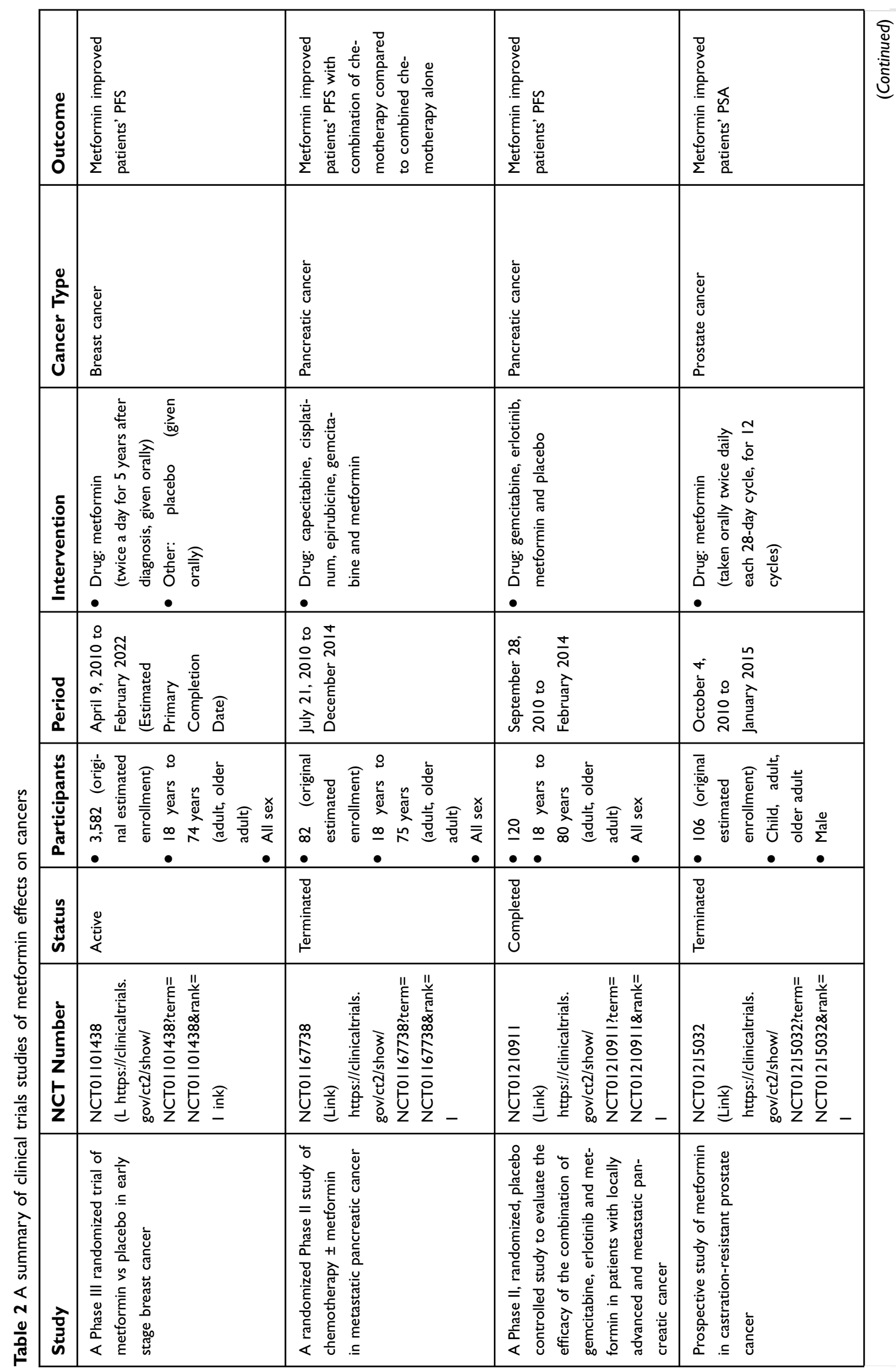




\begin{tabular}{|c|c|c|c|c|c|}
\hline 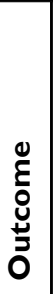 & 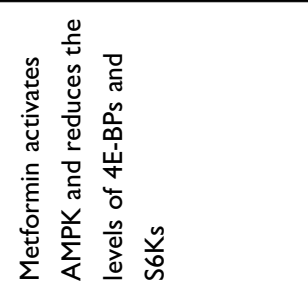 & 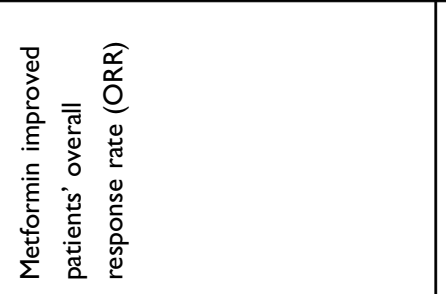 & 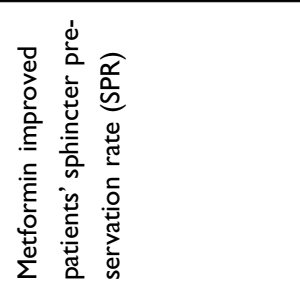 & 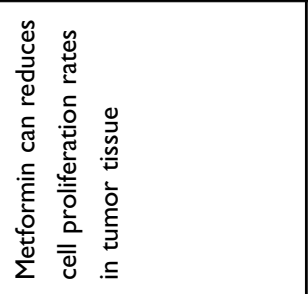 & 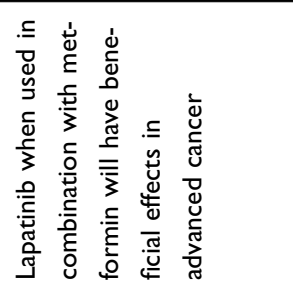 \\
\hline 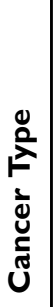 & 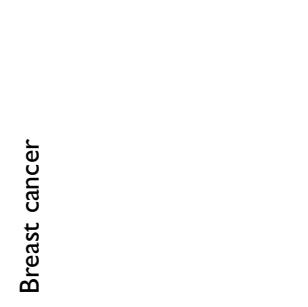 & 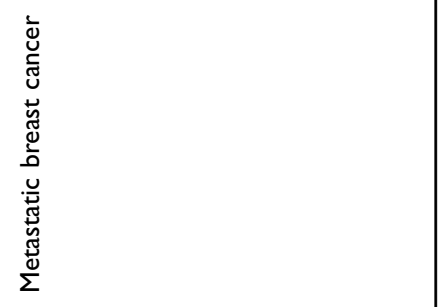 & 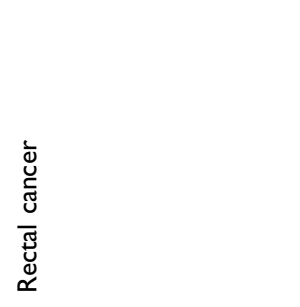 & 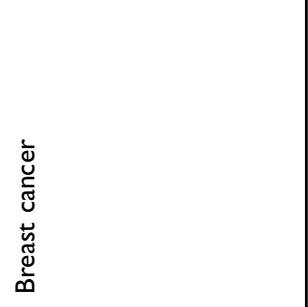 & 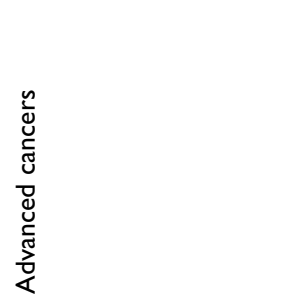 \\
\hline 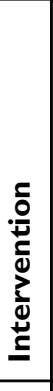 & 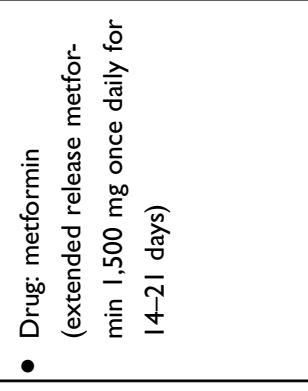 & 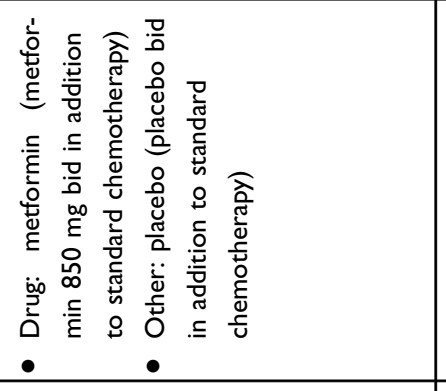 & 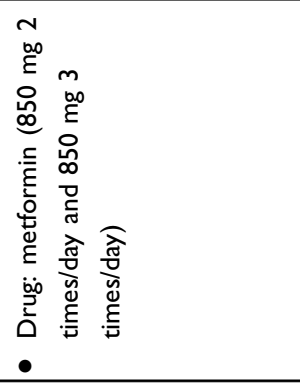 & 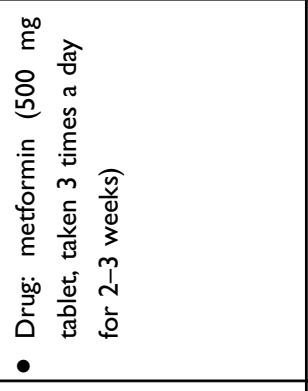 & 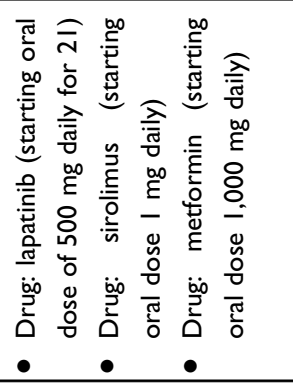 \\
\hline 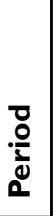 & 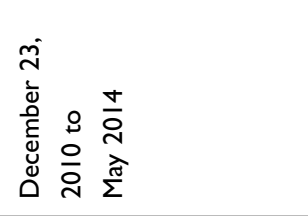 & 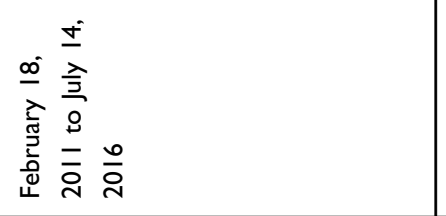 & 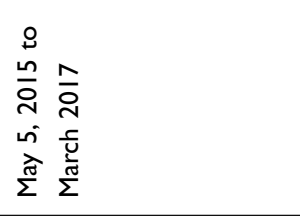 & 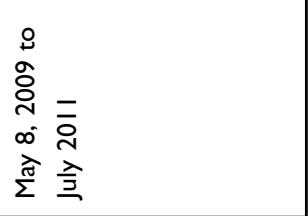 & 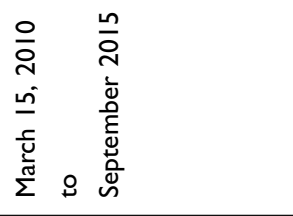 \\
\hline 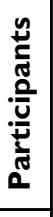 & 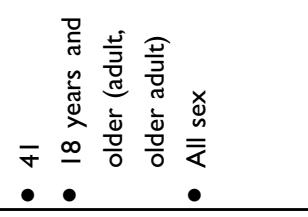 & 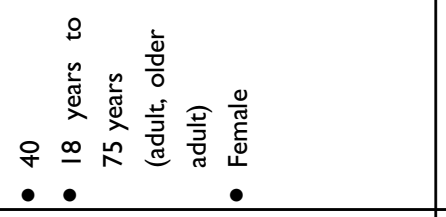 & 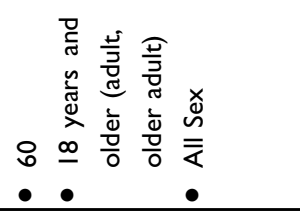 & 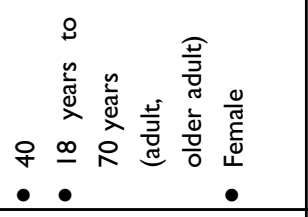 & 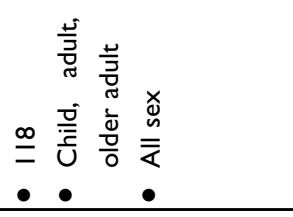 \\
\hline 总 & 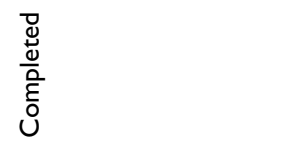 & 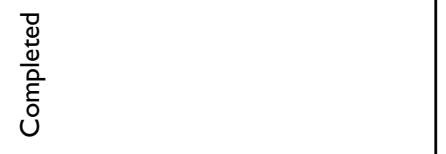 & 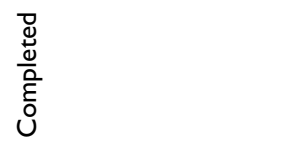 & 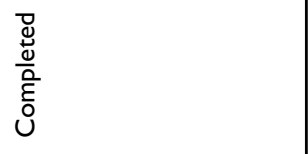 & 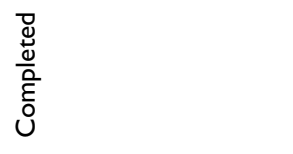 \\
\hline 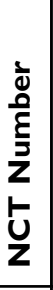 & 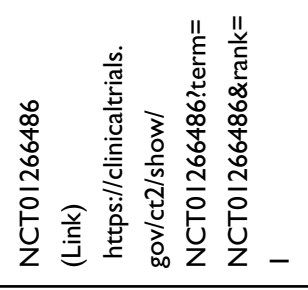 & 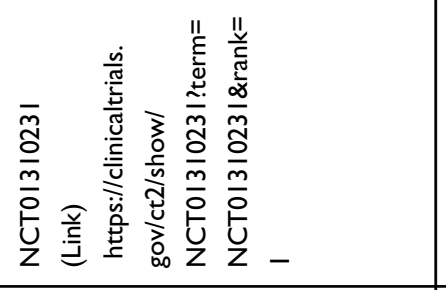 & 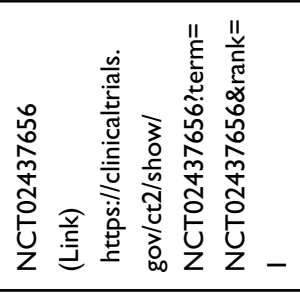 & 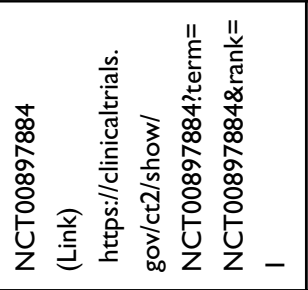 & 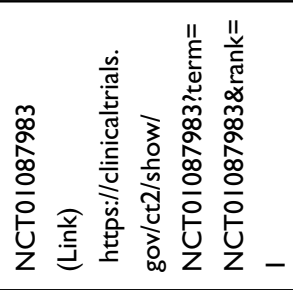 \\
\hline $\begin{array}{l}\text { ते } \\
\dot{\vec{\nu}}\end{array}$ & 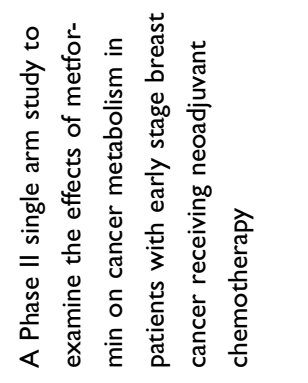 & 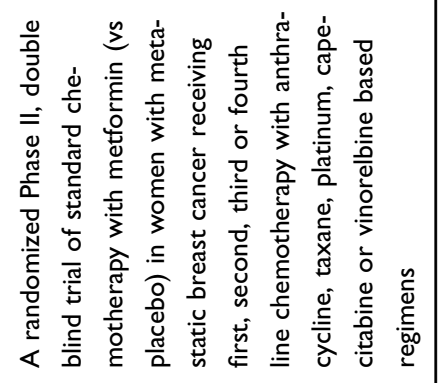 & 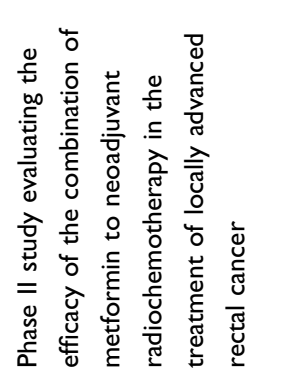 & 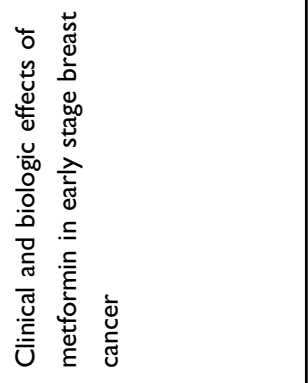 & 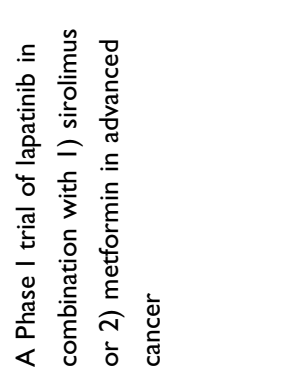 \\
\hline
\end{tabular}




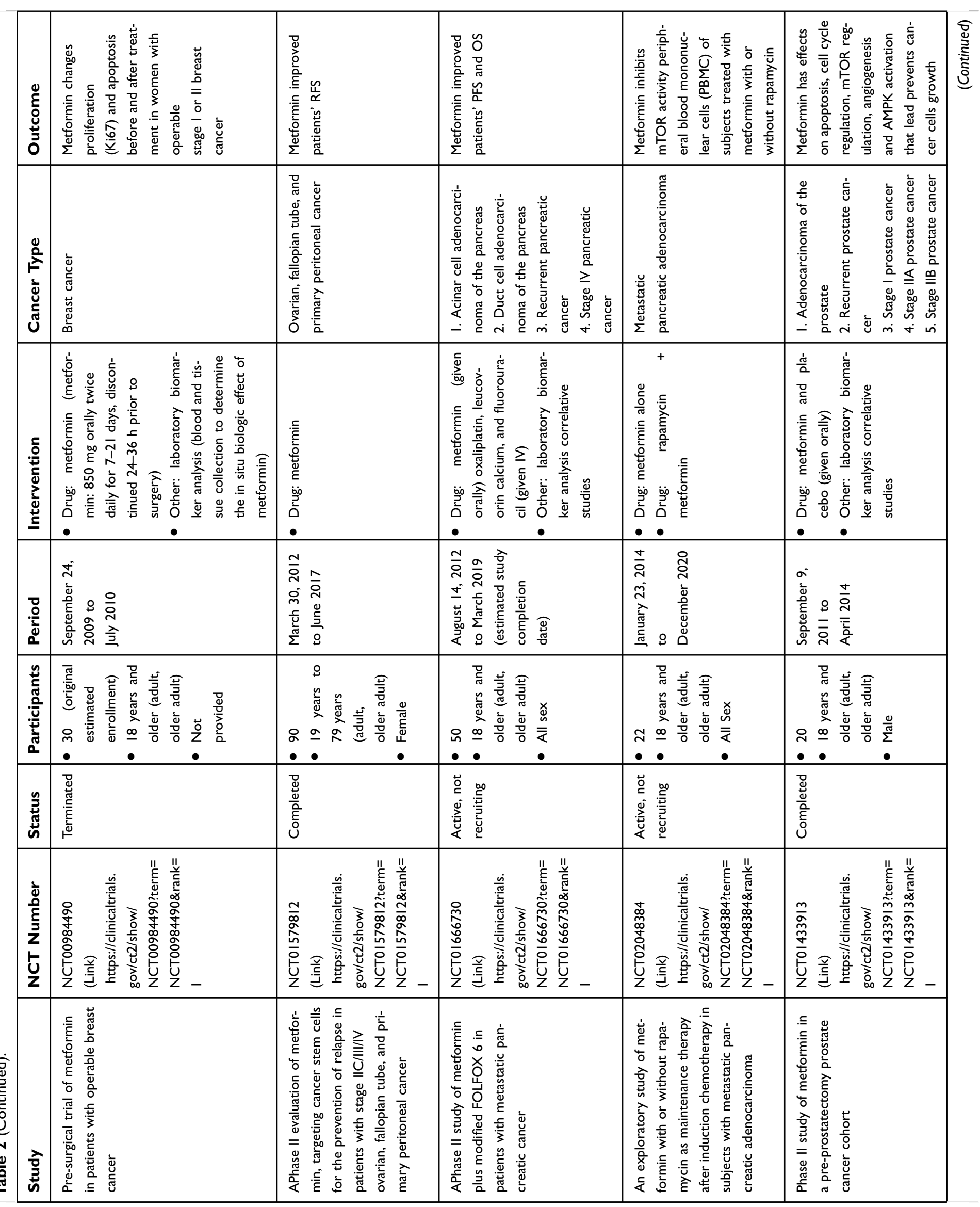




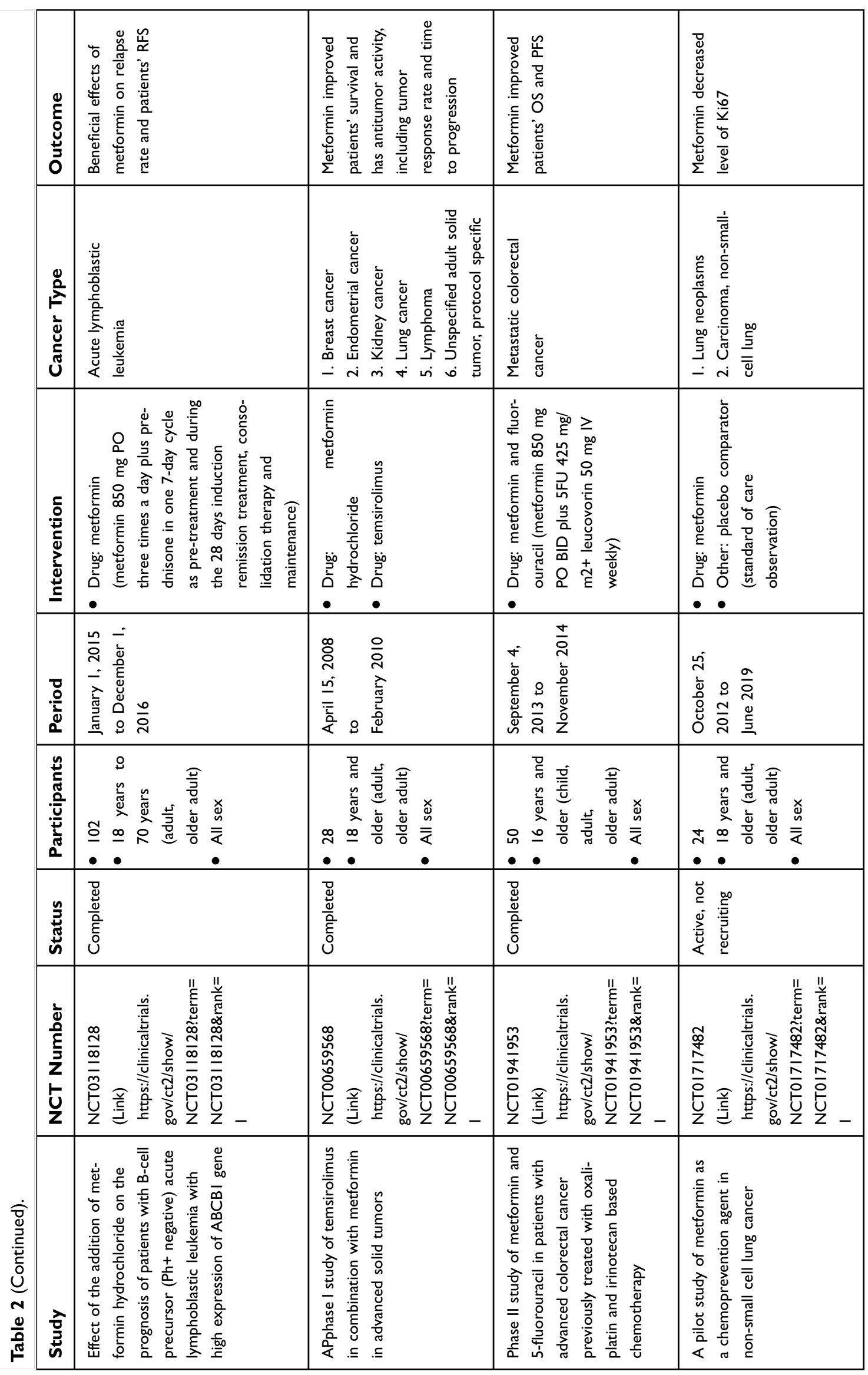


along with metformin. ${ }^{10,106}$ Using radiotherapy along with metformin reduced the incidence of death by $48 \%$, according to a study by Alan dal pra et al which was carried out on 4,000 diabetic men patients with prostate cancer. ${ }^{22}$ Moreover, they claimed that metformin causes tumor reoxygenation, and thereby the therapeutic response to radiotherapy will increase among patients with cancer (in terms of tumor hypoxia and resistance to radiation). ${ }^{22}$

\section{Conclusion and future vision}

According to the published results of clinical, experimental and animal models, the effectivity of metformin in cancer treatment is influenced by four different factors: 1) hypoxia of cancer cells;,2) amount of cancer stem cells;, 3) intrinsic sensitivity of cells;, and 4) growth and proliferation of cancer cells. All the material and evidence available reflect the anti-tumor properties of metformin. This drug can be used as a complementary therapeutic agent for cancer treatment. Given the potential of metformin in the treatment of cancer, it can be safely used in radiotherapy and chemotherapy to improve therapeutic response in ADT (androgen deprivation therapy). According to published evidence, metformin can also be used for the prevention of various cancers types. Therefore, based on evidence, metformin can be used widely in relation to prostate, colon, rectum, breast, esophagus, pancreas, liver cancers, etc., which are epidemic in modern societies, because, according to all the reputable published data and articles, metformin can: 1) reduce the likelihood of cancer incidence; 2) reduce the mortality of cancers; 3) increase the response to treatment in cancer cells when using radiotherapy and chemotherapy; 4) reduce the tumor movement and malignity; 5) reduce the likelihood of relapse; 6) reduce the damaging effects of ADT. Moreover, metformin can be considered as an ideal candidate for cancer prevention, improvement in the treatment of cancers and non-malignancy of tumors. In order to achieve this, we need more extensive research and information about the antitumor effects of metformin in nondiabetic patients; and more information is required on biology and genetics of various cells and radiotherapy. This article is intended to take a step towards the better treatment of cancer and its related conditions, and early diagnosing or treatment of cancer patients, and in general improve, the well being of affected families in particular and societies in general.

Metformin is a very good option for treating cancer in a complementary way. The properties of metformin that have led to the extensive studies on it include its stability (lack of change), the fact that it causes no or negligible problems in the body, it has no or less interference with other therapies, it is cheap and is commonly available. However, the anti-tumor effects of metformin on hyperglycemia require more research and studies. Also, regarding the efficacy of metformin in the treatment of cancer, we need more information on the processes of AMPK, LKB1, mTOR, suppressors involved in the mechanism of metformin such as p53, p21, insulin levels and its mechanism of action in the cell, and the body mass index of the patients being treated.

One of the main points that should be discussed about metformin use in the treatment of cancer is genetic polymorphisms; more information is required in this area and this will be the future subject for in-depth studies. It is not clear why metformin improved the therapeutic response in some patients and did not change it in some other patients. There is no ambiguity in the response to treatment. Therefore, we need more information about the factors involved in the effectiveness of metformin in cancer treatment. One important point regarding the efficacy of metformin in the treatment of cells is that the tumor response to the treatment is heavily dependent on cell genetics, which needs our future consideration in thorough research and modern designs of therapies in cancer diagnosis and treatment worldwide.

\section{Abbreviations}

4E-BPs, 4E-binding proteins; A549, lung carcinoma; ACC, acetyl coenzyme A carboxylase; ACE, aberrant crypt foci; ADP, adenosine diphosphate; ADT, androgen derivatives; Akt, PKB, protein kinase B; AMP, adenosine monophosphate; AMPK, AMP-activated kinase; ATM, ataxia telangiectasia mutated; ATP, adenosine triphosphate; CDK, cyclin-dependent kinase; CSS, cancerspecific survival; DNA, deoxyribonucleic acid; ETC, electron transfer chain; FAS, fatty acid synthase; HbA1c, glycated haemoglobin; HCT16, colon carcinoma; HER2, erb-B2, epidermal growth factor receptor 2; HIF-1, hypoxic inducible factor; HNSCC, head and neck squamous cell carcinoma; IGF, insulin-like growth factor; IGF$\mathrm{R}$, insulin-like growth factor receptor; IRS, insulin receptor substrate; Ki67, a marker for cell proliferation; LKB1, liver kinase B1; MAPK, mitogen-activated protein kinase; MCA, metachronous colorectal adenomas; MEF, mouse embryonic fibroblasts; mGPD, mitochondrial glycrophosphate 3 dehydrogenase; mTOR, mammalian target of 
rapamycin; NAFLD, non-alcoholic fatty liver disease; OCT-1, organic cation transporter 1; OCT-3, organic cation transporter 3; ORR, overall response rate; $\mathrm{p} 21$, a tumor suppressor gene; p53, a tumor suppressor gene; PBMC, peripheral blood mononuclear cells; PCOS, polycystic ovarian syndrome; pCR, pathologic complete response; PFS, progression-free survival; PI3K, phosphoinositide 3-kinase; PSA, prostate-specific antigen; RFO, recurrence free overall; RFS, recurrence-free survival; ROS, reactive oxygen species; S6Ks, ribosomal protein S6 kinase; SPR, sphincter preservation rate; T1DM, type 1 diabetes mellitus; T2DM, type 2 diabetes mellitus; TCS, therapy-induced cellular senescence; TSC2, tuberculous sclerosis complex 2; UPR, unfolded protein response;

\section{Author contributions}

All authors contributed to data analysis, drafting and revising the article, gave final approval of the version to be published and agree to be accountable for all aspects of the work.

\section{Disclosure}

The authors report no conflicts of interest in this work.

\section{References}

1. Hanahan D, Weinberg RA. Hallmarks of cancer: the next generation. Cell. 2011;144(5):646-674. doi:10.1016/j.cell.2011.02.013

2. Hanahan D, Weinberg RA. The hallmarks of cancer. Cell. 2000;100 (1):57-70.

3. Kasznicki J, Sliwinska A, Drzewoski J. Metformin in cancer prevention and therapy. Ann Transl Med. 2014;2(6):57. doi:10.3978/j. issn.2305-5839.2014.06.01

4. Algaonker SS. Diabetes mellitus as seen in Ancient Ayurvedic Medicine. Bajaj AS, editor. Insulin and Metabolism. Bombay (India): Indian Press. 1972;13-20.

5. Bailey CJ. Metformin: historical overview. Diabetologia. 2017;60 (9):1566-1576. doi:10.1007/s00125-017-4318-z

6. Miles JM, Rule AD, Borlaug BA. Use of metformin in diseases of aging. Curr Diab Rep. 2014;14(6):490. doi:10.1007/s11892014-0490-4

7. Gul W. Metformin: methods of analysis and its role in lowering the risk of cancer. J Bioequiv Availab. 2016;8:254-259. doi:10.4172/jbb

8. Dawes G, Mott J. Circulatory and respiratory reflexes caused by aromatic guanidines. Br J Pharmacol Chemother. 1950;5(1):65-76.

9. Suissa S, Azoulay L. Metformin and cancer: mounting evidence against an association. Diabetes Care. 2014;37(7):1786-1788. doi:10.2337/dc14-0500

10. Whitburn J, Edwards CM, Sooriakumaran P. Metformin and prostate cancer: a new role for an old drug. Curr Urol Rep. 2017;18 (6):46. doi:10.1007/s11934-017-0693-8

11. Samsuri NAB, Leech M, Marignol L. Metformin and improved treatment outcomes in radiation therapy-A review. Cancer Treat Rev. 2017;55:150-162. doi:10.1016/j.ctrv.2017.03.005

12. Watanabe C. Studies in the metabolic changes induced by administration of guanidine bases. II. The influence of guanidine upon urinary ammonia and acid secretion. J Biol Chem. 1918;34:51.
13. Asmal AC, Marble A. Oral hypoglycaemic agents. Drugs. 1984;28 (1):62-78. doi:10.2165/00003495-198428010-00004

14. Viollet B, Guigas B, Garcia NS, Leclerc J, Foretz M, Andreelli F. Cellular and molecular mechanisms of metformin: an overview. Clin Sci. 2012;122(6):253-270. doi:10.1042/CS20110386

15. Cantoria MJC. The Effects of Metformin on Pancreatic Cancer Metabolism. 2014.

16. Dowling RJ, Goodwin PJ, Stambolic V. Understanding the benefit of metformin use in cancer treatment. BMC Med. 2011;9(1):33. doi:10.1186/1741-7015-9-33

17. Malek M, Aghili R, Emami Z, Khamseh ME. Risk of cancer in diabetes: the effect of metformin. ISRN Endocrinol. 2013:2013.

18. Rêgo DF, Pavan LMC, Elias ST, Canto GDL, Guerra ENS. Effects of metformin on head and neck cancer: a systematic review. Oral Oncol. 2015;51(5):416-422. doi:10.1016/j.oraloncology.2015.01.007

19. Zaharenko L. Pharmacogenetics of Efficiency and Tolerance of the Peroral Antidiabetic Drug Metformin. Riga: University of Latvia; 2015.

20. Kourelis TV, Siegel RD. Metformin and cancer: new applications for an old drug. Med Oncol. 2012;29(2):1314-1327. doi:10.1007/ s12032-011-9846-7

21. Spillane SC, Bennett K, Sharp L, Barron TI. A cohort study of metformin exposure and survival in patients with stage I-III colorectal cancer .Cancer Epidemiol Prev Biomarkers. 2013. cebp. 0347.2013. doi:10.1158/1055-9965.EPI-13-0347

22. Foretz M, Guigas B, Bertrand L, Pollak M, Viollet B. Metformin: from mechanisms of action to therapies. Cell Metab. 2014;20 (6):953-966. doi:10.1016/j.cmet.2014.09.018

23. Muaddi H, Chowdhury S, Vellanki R, Zamiara P, Koritzinsky M. Contributions of AMPK and p53 dependent signaling to radiation response in the presence of metformin. Radiother Oncol. 2013;108 (3):446-450. doi:10.1016/j.radonc.2013.06.014

24. Cantoria MJ, Patel H, Boros LG, Meuillet EJ; Metformin and Pancreatic Cancer Metabolism. Pancreatic Cancer-Insights into Molecular Mechanisms and Novel Approaches to Early Detection and Treatment. London, UK: IntechOpen; 2014.

25. Del Barco S, Vazquez-Martin A, Cufí S, et al. Metformin: multi-faceted protection against cancer. Oncotarget. 2011;2 (12):896. doi:10.18632/oncotarget.241

26. Stumvoll M, Nurjhan N, Perriello G, Dailey G, Gerich JE. Metabolic effects of metformin in non-insulin-dependent diabetes mellitus. N Engl J Med. 1995;333(9):550-554. doi:10.1056/ NEJM199508313330903

27. Pasquali R, Gambineri A, Biscotti D, et al. Effect of long-term treatment with metformin added to hypocaloric diet on body composition, fat distribution, and androgen and insulin levels in abdominally obese women with and without the polycystic ovary syndrome. J Clin Endocrinol Metab. 2000;85(8):2767-2774. doi: $10.1210 /$ jcem. 85.8 .6738

28. Mazza A, Fruci B, Garinis GA, Giuliano S, Malaguarnera R, Belfiore A. The role of metformin in the management of NAFLD. Exp Diabetes Res. 2011;2012.

29. Ghatak SB, Dhamecha PS, Bhadada SV, Panchal SJ. Investigation of the potential effects of metformin on atherothrombotic risk factors in hyperlipidemic rats. Eur J Pharmacol. 2011;659(2-3):213-223. doi:10.1016/j.ejphar.2011.03.029

30. Ou H-Y, Cheng J-T, Yu E, Wu T-J. Metformin increases insulin sensitivity and plasma $\beta$-endorphin in human subjects. Hormone Metab Res. 2006;38(02):106-111. doi:10.1055/s-2006-925128

31. Hundal RS, Krssak M, Dufour S, et al. Mechanism by which metformin reduces glucose production in type 2 diabetes. Diabetes. 2000;49(12):2063-2069.

32. Schatz H. Metformin in type 1 diabetes reduces insulin requirements without significantly improving glycaemic control. Diabetologia. 2010;53(10):2264-2265. doi:10.1007/s00125-0101844-3 
33. Rowan JA, Hague WM, Gao W, Battin MR, Moore MP. Metformin versus insulin for the treatment of gestational diabetes. $N$ Engl $J$ Med. 2008;358(19):2003-2015. doi:10.1056/NEJMoa0707193

34. Bianchi C, Penno G, Romero F, Del Prato S, Miccoli R. Treating the metabolic syndrome. Expert Rev Cardiovasc Ther. 2007;5 (3):491-506. doi:10.1586/14779072.5.3.491

35. Diamanti-Kandarakis E, Economou F, Palimeri S, Christakou C. Metformin in polycystic ovary syndrome. Ann N Y Acad Sci. 2010;1205(1):192-198. doi:10.1111/j.1749-6632.2010.05679.x

36. Gwinn DM, Shackelford DB, Egan DF, et al. AMPK phosphorylation of raptor mediates a metabolic checkpoint. Mol Cell. 2008;30 (2):214-226. doi:10.1016/j.molcel.2008.03.003

37. Anisimov VN, Berstein LM, Egormin PA, et al. Effect of metformin on life span and on the development of spontaneous mammary tumors in HER-2/neu transgenic mice. Exp Gerontol. 2005;40 (8):685-693. doi:10.1016/j.exger.2005.07.007

38. Dowling RJ, Zakikhani M, Fantus IG, Pollak M, Sonenberg N. Metformin inhibits mammalian target of rapamycin-dependent translation initiation in breast cancer cells. Cancer Res. 2007;67 (22):10804-10812. doi:10.1158/0008-5472.CAN-07-2310

39. Alimova IN, Liu B, Fan Z, et al. Metformin inhibits breast cancer cell growth, colony formation and induces cell cycle arrest in vitro. Cell Cycle. 2009;8(6):909-915. doi:10.4161/cc.8.6.7933

40. Ooi GT, Tseng L, Tran MQ, Rechler MM. Insulin rapidly decreases insulin-like growth factor-binding protein-1 gene transcription in streptozotocin-diabetic rats. Mol Endocrinol. 1992;6 (12):2219-2228. doi:10.1210/mend.6.12.1283442

41. Saito S, Furuno A, Sakurai J, et al. Chemical genomics identifies the unfolded protein response as a target for selective cancer cell killing during glucose deprivation. Cancer Res. 2009;69 (10):4225-4234. doi:10.1158/0008-5472.CAN-08-2689

42. Hirsch HA, Iliopoulos D, Tsichlis PN, Struhl K. Metformin selectively targets cancer stem cells, and acts together with chemotherapy to block tumor growth and prolong remission. Cancer Res. 2009;69(19):7507-7511. doi:10.1158/0008-5472. CAN-09-2994

43. Vazquez-Martin A, Oliveras-Ferraros C, Cufí S, Del Barco S, Martin-Castillo B, Menendez JA. Metformin regulates breast cancer stem cello ntogeny by transcriptional regulation of the epithelial-mesenchymal transition (EMT) status. Cell Cycle. 2010;9(18):3831-3838. doi:10.4161/cc.9.19.13324

44. Choi MK, Jin QR, Jin HE, et al. Effects of tetraalkylammonium compounds with different affinities for organic cation transporters on the pharmacokinetics of metformin. Biopharm Drug Dispos. 2007;28(9):501-510. doi:10.1002/(ISSN)1099-081X

45. Wright SH. Role of organic cation transporters in the renal handling of therapeutic agents and xenobiotics. Toxicol Appl Pharmacol. 2005;204(3):309-319. doi:10.1016/j.taap.2004.10.021

46. Jonker JW, Schinkel AH. Pharmacological and physiological functions of the polyspecific organic cation transporters: OCT1, 2, and 3 (SLC22A1-3). $J$ Pharmacol Exp Ther. 2004;308(1):2-9. doi:10.1124/jpet.103.053298

47. Wheaton WW, Weinberg SE, Hamanaka RB, et al. Metformin inhibits mitochondrial complex I of cancer cells to reduce tumorigenesis. Elife. 2014;3:e2242. doi:10.7554/eLife.02242

48. Madiraju AK, Erion DM, Rahimi Y, et al. Metformin suppresses gluconeogenesis by inhibiting mitochondrial glycerophosphate dehydrogenase. Nature. 2014;510(7506):542. doi:10.1038/nature 13270

49. Zhou G, Myers R, Li Y, et al. Role of AMP-activated protein kinase in mechanism of metformin action. $J$ Clin Invest. 2001;108 (8):1167-1174. doi:10.1172/JCI13505

50. Doran E, Halestrap AP. Evidence that metformin exerts its anti-diabetic effects through inhibition of complex 1 of the mitochondrial respiratory chain. Biochem J. 2000;348(3):607-614.
51. Zakikhani M, Dowling RJ, Sonenberg N, Pollak MN. The effects of adiponectin and metformin on prostate and colon neoplasia involve activation of AMP-activated protein kinase. Cancer Prev Res. 2008;1(5):369-375. doi:10.1158/1940-6207.CAPR-08-0081

52. Todd JN, Florez JC. An update on the pharmacogenomics of metformin: progress, problems and potential. Pharmacogenomics. 2014;15 (4):529-539. doi:10.2217/pgs.14.21

53. Schäfer G. Site-specific uncoupling and inhibition of oxidative phosphorylation by biguanides. II. Biochim Biophys Acta. 1969;172(2):334-337.

54. El-Mir M-Y, Nogueira V, Fontaine E, Avéret N, Rigoulet M, Leverve X. Dimethylbiguanide inhibits cell respiration via an indirect effect targeted on the respiratory chain complex I. J Biochem Physiol. 2000;275(1):223-228.

55. Scotland S, Saland E, Skuli N, et al. Mitochondrial energetic and AKT status mediate metabolic effects and apoptosis of metformin in human leukemic cells. Leukemia. 2013;27(11):2129. doi:10.1038/leu.2013.107

56. Dykens JA, Jamieson J, Marroquin L, Nadanaciva S, Billis PA, Will Y. Biguanide-induced mitochondrial dysfunction yields increased lactate production and cytotoxicity of aerobically-poised HepG2 cells and human hepatocytes in vitro. Toxicol Appl Pharmacol. 2008;233(2):203-210. doi:10.1016/j.taap.2008.08.013

57. Guigas B, Detaille D, Chauvin C, et al. Metformin inhibits mitochondrial permeability transition and cell death: a pharmacological in vitro study. Biochem J. 2004;382(3):877-884. doi:10.1042/BJ20040885

58. Whitaker-Menezes D, Martinez-Outschoorn UE, Flomenberg N, et al. Hyperactivation of oxidative mitochondrial metabolism in epithelial cancer cells in situ: visualizing the therapeutic effects of metformin in tumor tissue. Cell Cycle. 2011;10(23):4047-4064. doi:10.4161/ cc.10.23.18151

59. Steinberg GR, Kemp BE. AMPK in health and disease. Physiol Rev. 2009;89(3):1025-1078. doi:10.1152/physrev.00011.2008

60. Carling D. AMPK signalling in health and disease. Curr Opin Cell Biol. 2017;45:31-37. doi:10.1016/j.ceb.2017.01.005

61. Huang X, Wullschleger S, Shpiro N, et al. Important role of the LKB1AMPK pathway in suppressing tumorigenesis in PTEN-deficient mice. Biochem J. 2008;412(2):211-221. doi:10.1042/BJ20080557

62. Polivka J Jr, Janku F. Molecular targets for cancer therapy in the PI3K/AKT/mTOR pathway. Pharmacol Ther. 2014;142 (2):164-175. doi:10.1016/j.pharmthera.2013.12.004

63. Oh BY, Park YA, Huh JW, et al. Metformin enhances the response to radiotherapy in diabetic patients with rectal cancer. J Cancer Res Clin Oncol. 2016;142(6):1377-1385. doi:10.1007/s00432-016-2148-x

64. Foretz M, Hebrard S, Leclerc J, et al. Metformin inhibits hepatic gluconeogenesis in mice independently of the LKB1/AMPK pathway via a decrease in hepatic energy state. J Clin Invest. 2010;120 (7):2355-2369. doi:10.1172/jci40671

65. Kalender A, Selvaraj A, Kim SY, et al. Metformin, independent of AMPK, inhibits mTORC1 in a rag GTPase-dependent manner. Cell Metab. 2010;11(5):390-401. doi:10.1016/j.cmet.2010.03.014

66. Shaw RJ, Lamia KA, Vasquez D, et al. The kinase LKB1 mediates glucose homeostasis in liver and therapeutic effects of metformin. Science (New York, NY). 2005;310(5754):1642-1646. doi:10.1126/ science.1120781

67. Zannella VE, Dal Pra A, Muaddi H, et al. Reprogramming metabolism with metformin improves tumor oxygenation and radiotherapy response. Clin Cancer Res. 2013;19(24):6741-6750. doi:10.1158/1078-0432.ccr-13-1787

68. Storozhuk Y, Hopmans SN, Sanli T, et al. Metformin inhibits growth and enhances radiation response of non-small cell lung cancer (NSCLC) through ATM and AMPK. $B r \quad J$ Cancer. 2013;108(10):2021-2032. doi:10.1038/bjc.2013.187

69. Song CW, Lee H, Dings RP, et al. Metformin kills and radiosensitizes cancer cells and preferentially kills cancer stem cells. Sci Rep. 2012;2:362. doi:10.1038/srep00362 
70. Zhang T, Zhang L, Zhang T, et al. Metformin sensitizes prostate cancer cells to radiation through EGFR/p-DNA-PKCS in vitro and in vivo. Radiat Res. 2014;181(6):641-649. doi:10.1667/rr13561.1

71. Lee M-S, Hsu -C-C, Wahlqvist ML, Tsai H-N, Chang Y-H, Huang Y-C. Type 2 diabetes increases and metformin reduces total, colorectal, liver and pancreatic cancer incidences in Taiwanese: a representative population prospective cohort study of 800,000 individuals. BMC Cancer. 2011;11(1):20. doi:10.1186/1471-2407-11-20

72. Decensi A, Puntoni M, Goodwin P, et al. Metformin and cancer risk in diabetic patients: a systematic review and meta-analysis. Cancer Prev Res. 2010;3(11):1451-1461. doi:10.1158/1940-6207.capr-10-0157

73. Landman GW, Kleefstra N, van Hateren KJ, Groenier $\mathrm{KH}$, Gans RO, Bilo HJ. Metformin associated with lower cancer mortality in type 2 diabetes: ZODIAC-16. Diabetes Care. 2010;33 (2):322-326. doi:10.2337/dc09-1380

74. Currie CJ, Poole CD, Gale EA. The influence of glucose-lowering therapies on cancer risk in type 2 diabetes. Diabetologia. 2009;52 (9):1766-1777. doi:10.1007/s00125-009-1440-6

75. Soranna D, Scotti L, Zambon A, et al. Cancer risk associated with use of metformin and sulfonylurea in type 2 diabetes: a meta-analysis. Oncologist. 2012;17(6):813-822. doi:10.1634/theoncologist.2011-0462

76. Noto $\mathrm{H}$, Goto A, Tsujimoto T, Noda M. Cancer risk in diabetic patients treated with metformin: a systematic review and meta-analysis. PLoS One. 2012;7(3):e33411. doi:10.1371/journal. pone. 0033411

77. Higurashi T, Hosono K, Takahashi H, et al. Metformin for chemoprevention of metachronous colorectal adenoma or polyps in post-polypectomy patients without diabetes: a multicentre double-blind, placebo-controlled, randomised phase 3 trial. The Lancet Oncol. 2016;17(4):475-483. doi:10.1016/s1470-2045(15) 00565-3

78. Joshua AM, Zannella VE, Downes MR, et al. A pilot 'window of opportunity' neoadjuvant study of metformin in localised prostate cancer. Prostate Cancer Prostatic Dis. 2014;17(3):252-258. doi:10.1038/pcan.2014.20

79. Campagnoli C, Pasanisi P, Abba C, et al. Effect of different doses of metformin on serum testosterone and insulin in non-diabetic women with breast cancer: a randomized study. Clin Breast Cancer. 2012;12(3):175-182. doi:10.1016/j.clbc.2012.03.004

80. Monami M, Lamanna C, Balzi D, Marchionni N, Mannucci E. Sulphonylureas and cancer: a case-control study. Acta Diabetol. 2009;46(4):279. doi:10.1007/s00592-008-0083-2

81. Home P, Kahn S, Jones N, Noronha D, Beck-Nielsen H, Viberti G. Experience of malignancies with oral glucose-lowering drugs in the randomised controlled ADOPT (A Diabetes Outcome Progression Trial) and RECORD (Rosiglitazone Evaluated for Cardiovascular Outcomes and Regulation of Glycaemia in Diabetes) clinical trials. Diabetologia. 2010;53(9):1838-1845. doi:10.1007/s00125-010-1804-y

82. Baur DM, Klotsche J, Hamnvik O-PR, et al. Type 2 diabetes mellitus and medications for type 2 diabetes mellitus are associated with risk for and mortality from cancer in a German primary care cohort. Metabolism. 2011;60(10):1363-1371. doi:10.1016/j. metabol.2010.09.012

83. Li D, Yeung S-CJ, Hassan MM, Konopleva M, Abbruzzese JL. Antidiabetic therapies affect risk of pancreatic cancer. Gastroenterology. 2009;137(2):482-488. doi:10.1053/j.gastro. 2009.04.013

84. Berstein LM, Boyarkina MP, Tsyrlina EV, Turkevich EA, Semiglazov VF. More favorable progesterone receptor phenotype of breast cancer in diabetics treated with metformin. Med Oncol. 2011;28(4):1260-1263. doi:10.1007/s12032-010-9572-6

85. Rieken M, Kluth LA, Xylinas E, et al. Association of diabetes mellitus and metformin use with biochemical recurrence in patients treated with radical prostatectomy for prostate cancer. World J Urol. 2014;32(4):999-1005. doi:10.1007/s00345-013-1171-7
86. Spratt DE, Zhang C, Zumsteg ZS, Pei X, Zhang Z, Zelefsky MJ. Metformin and prostate cancer: reduced development of castration-resistant disease and prostate cancer mortality. Eur Urol. 2013;63(4):709-716. doi:10.1016/j.eururo.2012.12.004

87. Margel D, Urbach DR, Lipscombe LL, et al. Metformin use and all-cause and prostate cancer-specific mortality among men with diabetes. J Clin Oncol. 2013;31(25):3069-3075. doi:10.1200/ JCO.2012.46.7043

88. Libby G, Donnelly LA, Donnan PT, Alessi DR, Morris AD, Evans JM. New users of metformin are at low risk of incident cancer: a cohort study among people with type 2 diabetes. Diabetes Care. 2009;32(9):1620-1625. doi:10.2337/dc08-2175

89. Monami M, Colombi C, Balzi D, et al. Metformin and cancer occurrence in insulin-treated type 2 diabetic patients. Diabetes Care. 2011;34(1):129-131. doi:10.2337/dc10-1287

90. Bowker SL, Yasui Y, Veugelers P, Johnson JA. Glucose-lowering agents and cancer mortality rates in type 2 diabetes: assessing effects of time-varying exposure. Diabetologia. 2010;53 (8):1631-1637. doi:10.1007/s00125-010-1750-8

91. Bo S, Ciccone G, Rosato R, et al. Cancer mortality reduction and metformin: a retrospective cohort study in type 2 diabetic patients. Diabetes Obes Metab. 2012;14(1):23-29. doi:10.1111/j.14631326.2011.01480.x

92. Evans JM, Donnelly LA, Emslie-Smith AM, Alessi DR, Morris AD. Metformin and reduced risk of cancer in diabetic patients. BMJ (Clinical Research Ed.). 2005;330 (7503):1304-1305. doi:10.1136/bmj.38415.708634.F7

93. Coyle C, Cafferty FH, Vale C, Langley RE. Metformin as an adjuvant treatment for cancer: a systematic review and meta-analysis. Ann Oncol. 2016;27(12):2184-2195. doi:10.1093/ annonc/mdw410

94. Hosono K, Endo H, Takahashi H, et al. Metformin suppresses colorectal aberrant crypt foci in a short-term clinical trial. Cancer Prev Res. 2010;3(9):1077-1083. doi:10.1158/1940-6207.capr-100186

95. Garrett CR, Hassabo HM, Bhadkamkar NA, et al. Survival advantage observed with the use of metformin in patients with type II diabetes and colorectal cancer. $B r \quad J$ Cancer. 2012;106 (8):1374-1378. doi: $10.1038 /$ bjc. 2012.71

96. Oliveria SA, Koro CE, Ulcickas Yood M, Sowell M. Cancer incidence among patients treated with antidiabetic pharmacotherapy. Diabetes Metab Syndr. 2008;2(1):47-57. doi:10.1016/j. dsx.2007.11.002

97. Ruiter R, Visser LE, van Herk-Sukel MP, et al. Lower risk of cancer in patients on metformin in comparison with those on sulfonylurea derivatives: results from a large population-based follow-up study. Diabetes Care. 2012;35(1):119-124. doi:10.2337/dc11-0857

98. Bodmer M, Meier C, Krahenbuhl S, Jick SS, Meier CR. Long-term metformin use is associated with decreased risk of breast cancer. Diabetes Care. 2010;33(6):1304-1308. doi:10.2337/dc09-1791

99. Jiralerspong S, Palla SL, Giordano SH, et al. Metformin and pathologic complete responses to neoadjuvant chemotherapy in diabetic patients with breast cancer. J Clin Oncol. 2009;27(20):3297-3302. doi:10.1200/jco.2009.19.6410

100. Zhang Y, Storr SJ, Johnson K, et al. Involvement of metformin and AMPK in the radioresponse and prognosis of luminal versus basal-like breast cancer treated with radiotherapy. Oncotarget. 2014;5(24):12936-12949. doi:10.18632/ oncotarget. 2683

101. Kim EH, Kim MS, Cho CK, Jung WG, Jeong YK, Jeong JH. Low and high linear energy transfer radiation sensitization of HCC cells by metformin. J Radiat Res. 2014;55(3):432-442. doi:10.1093/jrr/ rrt131

102. Aldea MD, Petrushev B, Soritau O, et al. Metformin plus sorafenib highly impacts temozolomide resistant glioblastoma stem-like cells. J BUON. 2014;19(2):502-511. 
103. Haugrud AB, Zhuang Y, Coppock JD, Miskimins WK Dichloroacetate enhances apoptotic cell death via oxidative damage and attenuates lactate production in metformin-treated breast cancer cells. Breast Cancer Res Treat. 2014;147(3):539-550. doi:10.1007/ s10549-014-3128-y

104. Skinner HD, McCurdy MR, Echeverria AE, et al. Metformin use and improved response to therapy in esophageal adenocarcinoma. Acta Oncol. 2013;52(5):1002-1009. doi:10.3109/0284186x.2012.718096
105. Baskar R, Dai J, Wenlong N, Yeo R, Yeoh K-W. Biological response of cancer cells to radiation treatment. Front Mol Biosci. 2014;1:24. doi:10.3389/fmolb.2014.00024

106. Iliopoulos D, Hirsch HA, Struhl K. Metformin decreases the dose of chemotherapy for prolonging tumor remission in mouse xenografts involving multiple cancer cell types. Cancer Res. 2011;71 (9):3196-3201. doi:10.1158/0008-5472.can-10-3471

\section{Publish your work in this journal}

Cancer Management and Research is an international, peer-reviewed open access journal focusing on cancer research and the optimal use of preventative and integrated treatment interventions to achieve improved outcomes, enhanced survival and quality of life for the cancer patient.
The manuscript management system is completely online and includes a very quick and fair peer-review system, which is all easy to use. Visit http://www.dovepress.com/testimonials.php to read real quotes from published authors. 